\title{
Inter-individual variations in cadmium and zinc biodynamics in the scallop Chlamys nobilis
}

\author{
Ke Pan, Wen-Xiong Wang*
}

Department of Biology, The Hong Kong University of Science and Technology (HKUST), Clear Water Bay, Kowloon, Hong Kong

\begin{abstract}
Intraspecific variability in the bioaccumulation of metals has been widely recorded in marine invertebrates, including marine bivalves. In the present study, we used biokinetic modelling and metal subcellular partitioning approaches to understand the intraspecific variability of metal bioaccumulation ( $\mathrm{Cd}$ and $\mathrm{Zn}$ ) in the scallop Chlamys nobilis as a model organism. Significant individual differences in metal body burdens were found in C. nobilis. Cd concentrations varied by 3-fold and concentrations of $\mathrm{Zn}$ varied by 10 -fold for individuals with similar body sizes. Contrasting metal biokinetics and metal subcellular partitioning were observed in different individuals. There was no significant relationship between the metal body burden and the dissolved metal uptake rate or the dietary assimilation efficiency in the individual scallops. However, a significant negative relationship was found between the metal efflux rate and the respective metal body burden, suggesting that efflux rate plays a key role in determining the intraspecific differences in the metal body burden in the tissues of scallops. Subcellular partitioning was closely related to the metal body burden in the scallops as well. A lower efflux rate or a higher proportion of metals stored in non-toxic form contributed to higher metal body burdens in individual scallops. Intrinsic variation may provide a population with more plasticity to counteract spatially or temporally abrupt environmental changes, and may be important for survival of microevolutionary events. Our results provide important information for interpreting the variability observed in natural environments.
\end{abstract}

KEY WORDS: Cadmium $\cdot$ Zinc $\cdot$ Scallops $\cdot$ Biokinetic model $\cdot$ Intraspecific difference Resale or republication not permitted without written consent of the publisher

\section{INTRODUCTION}

Marine invertebrates accumulate metals at varying concentrations and the natural variability of metal bioaccumulation has been well recognized. One wellknown example of this variability is the interspecific difference in metal bioaccumulation. Vastly different metal concentrations can be found in co-existing species because of variable accumulation patterns and detoxification strategies among species (Rainbow 2002, Wang \& Rainbow 2008). Barnacles and oysters, for example, typically accumulate higher Zn concentrations than mussels and clams (Luoma \& Rainbow 2005). However, metal bioaccumulation among individuals in a given species can also be highly variable. The intraspecific variability, or inherent variability (Rainbow \& Luoma 2008), of metal bioaccumulation has been widely recorded (Phillips \& Rainbow 1988,
Gay \& Maher 2003). Strikingly different accumulated concentrations of metals in different individuals from the same location can be found, even at unpolluted sites (Wang \& Wong 2006). For example, Zauke \& Petri (1993) reported 2- to 10-fold intraspecific variation in $\mathrm{Cd}, \mathrm{Cu}$ and $\mathrm{Zn}$ concentrations in Antarctic crustaceans. The influence of intra-sample variability in interpreting the biomonitoring data has been addressed (Daskalakis 1996). In biomonitoring programs, the observed metal contaminant levels are usually compared with data from clean (reference) sites. The natural intraspecific variability however creates background noise that reduces the power to detect any changes caused by altered metal bioavailability (Phillips \& Rainbow 1993) and therefore presents an on-going puzzle for environmental regulators. One solution is to increase the size of pooled samples in biomonitoring programs to obtain smaller intrasample variability. 
Intraspecific variability of metal bioaccumulation can be induced by a series of abiotic and biotic factors. Abiotic factors include spatial heterogeneity and food conditions. A previous study showed that Chlamys nobilis accumulated $\mathrm{Cd}$ and $\mathrm{Zn}$ differently when food availability and food quality varied, although metal concentrations in the varied food environments were comparable (Pan \& Wang 2008a). Other studies tried to attribute intraspecific metal variability to age, sex, condition status and seasonal variation of somatic tissues (Zauke \& Petri 1993). Gonadal development and spawning can significantly dilute or concentrate metal concentrations in the tissues of bivalves because of the different levels of metals in gonadal tissues (Cain \& Luoma 1986, Chan et al. 1999). Bustamante \& Miramand (2005) indicated that distribution of metals in body compartments (digestive gland, kidney, gill, gonad, adductor muscle) was the main factor causing the variability of $\mathrm{Cu}$ and $\mathrm{Zn}$ concentrations in the scallops Chlamys varia, compared with other factors such as season and body size. The underlying mechanisms, however, remain unexplained. Indeed, body size/ growth rate can greatly influence metal concentrations in tissues. Rapid growth leads to a dilution effect; metal concentrations thus decrease with increasing body size in natural populations (Mubiana et al. 2006). Interestingly, this relationship may be obscured because some data exceed 'high criteria' (Kang et al. 2000). Variability can also be observed in metal concentrations among similar-sized individuals of a given species collected at the same location and period (Pan \& Wang 2008b) and cannot be explained by the size effect.

The biokinetic model has demonstrated its ability to interpret the variability of metal bioaccumulation in nature (Wang \& Fisher 1996, Luoma \& Rainbow 2005). The model captures both environmental and physiological variability and has been successfully applied to explain interspecific and geographical differences in metal bioaccumulation in scallops in the field (Pan \& Wang 2008a, 2009). Despite these recent successes, the application of this model to explain intraspecific variability of metal bioaccumulation has not been demonstrated. In the present study, we seek to investigate the relationships between intraspecific variability and metal biokinetics, using the scallop Chlamys nobilis as a model organism. There has been increasing concern about the bioaccumulation of metals in scallops. Scallops have also been used as sentinel organisms in environmental monitoring; thus, there is a need for a clear understanding of the mechanisms underlying the natural variability of metal bioaccumulation in scallops. Significant individual differences in $\mathrm{Cd}$ and $\mathrm{Zn}$ concentrations were observed in our previous study (Pan \& Wang 2008b). We further used metal subcellular fractionation to illustrate the differences in metal partitioning in different individuals.

\section{MATERIALS AND METHODS}

Collection of experimental organisms. Scallops Chamys nobilis with similar shell sizes $(20 \pm 3 \mathrm{~mm})$ were obtained from an aquaculture farm in Dapeng Bay (eastern Hong Kong waters), Guangdong Province, China. All scallops were reared and grown in Dapeng Bay. They thus shared similar metal exposure histories. After collection, the scallops were cleaned of epibionts and acclimated in a 601 aerated flow-through system $\left(33 \mathrm{psu}, 20^{\circ} \mathrm{C}\right)$ for at least $1 \mathrm{wk}$ prior to the experiments. During the acclimation period, the scallops were fed the diatom Thalassiosira nordenskioeldii on a daily basis.

Metal uptake from the dissolved phase. A total of 30 individuals was used in this experiment. To measure metal uptake rates from the waterborne phase in scallops, the ${ }^{109} \mathrm{Cd}$ and ${ }^{65} \mathrm{Zn}$ radioisotopes (Eckert \& Ziegler Isotope Product; specific activity: $112.8 \mathrm{kBq} \mathrm{gg}^{-1}$ for $\mathrm{Cd}, 16.3 \mathrm{kBq} \mathrm{gg}^{-1}$ for $\mathrm{Zn}$ ) were spiked into $0.22 \mu \mathrm{m}$ filtered seawater (33 psu), both at a concentration of $7.4 \mathrm{kBq} \mathrm{l}^{-1}$ (equal to $0.066 \mu \mathrm{g} \mathrm{l}^{-1}$ for $\mathrm{Cd}$, and $0.45 \mu \mathrm{g} \mathrm{l}^{-1}$ for $\mathrm{Zn}$ ). The seawater was equilibrated overnight before the experiments. Each individual scallop was first weighed alive in air and then placed separately into a polypropylene beaker containing $200 \mathrm{ml}$ exposure medium for $2 \mathrm{~h}$. All individuals were found to have open shells and to pump water normally within $3 \mathrm{~min}$. Aliquots of the seawater $(3 \mathrm{ml})$ were sampled before and after exposure to measure the radioactivity in the seawater, and no significant decrease in radioactivity was observed $(<15 \%)$. After exposure, the scallops were removed, rinsed with filtered seawater and then dissected, and their soft tissues as a whole were measured for radioactivity. The tissues and shells were dried at $80^{\circ} \mathrm{C}$ to obtain the dry weights, after which the dry tissues were digested for $\mathrm{Cd}$ and $\mathrm{Zn}$ measurements (see below in 'Measurement of $\mathrm{Cd}$ and $\mathrm{Zn}$ concentrations').

The condition index of each scallop (CI) was calculated as (Crosby \& Gale 1990):

$$
\mathrm{CI}=\frac{\text { dry soft tissue wt }(\mathrm{g})}{\text { internal shell cavity capacity }(\mathrm{g})} \times 1000
$$

The shell cavity capacity of each scallop was determined by subtracting its dry shell weight (g) from its total whole live weight $(\mathrm{g})$.

The metal uptake rate constant for each individual was calculated as:

$$
k_{\mathrm{u}}=\frac{A_{\mathrm{tissue}}}{t \times A_{\mathrm{water}}}
$$


where $A_{\text {tissue }}\left(\mathrm{ccpm} \mathrm{g}{ }^{-1}\right.$, ccpm: corrected counting per minute) is the radioactivity in the tissue of the scallop, $t$ (d) is the uptake period, and $A_{\text {water }}\left(\mathrm{ccpm} \mathrm{^{-1 }}\right)$ is the radioactivity in the seawater.

Clearance rate experiment. In total, 57 scallops with similar shell length were chosen to investigate the relationships between metal body burden and the metal's clearance rate, assimilation efficiency and efflux rate. The filtration rates of the scallops were determined using the method described by Pan \& Wang (2008b). Briefly, the diatoms Thalassiosira nordenskioeldii were filtered and resuspended at a cell density of 5000 cells ml $\mathrm{m}^{-1}$ in $1 \mathrm{l}$ of $0.22 \mu \mathrm{m}$ filtered seawater $\left(20^{\circ} \mathrm{C}\right)$ containing 1 individual scallop. The algal suspension was maintained by a magnetic stirrer. At time intervals of $10 \mathrm{~min}, 10 \mathrm{ml}$ of water was sampled and the cell density was analyzed by a Beckman Coulter Counter. This procedure was repeated for each individual over 3 consecutive days. The weight-specific filtration rate was calculated with the following equation:

$$
\mathrm{FR}=\frac{\left(\ln C_{0}-\ln C_{t}\right) \times V}{W \times t}
$$

where FR is the filtration rate of scallops $\left(\mathrm{h} \mathrm{h}^{-1}\right), C_{t}$ is the cell density at time $t$ (cells $\mathrm{l}^{-1}$ ), $C_{0}$ is the initial cell density (cells $\mathrm{l}^{-1}$ ), $V$ is the volume of water (1), $W$ is the dry weight of scallop tissue, and $t$ is the duration of the experiment. Finally, the average value of 3 consecutive days' measurements was used.

Metal assimilation efficiency. Following the clearance rate measurements, the same scallops were immediately used for measuring the metal assimilation efficiency (AE). The pulse-chase feeding technique was employed to quantify the AEs in scallops, as described by Chong \& Wang (2000). The diatom Thalassiosira nordenskioeldii was used as food. It was grown in $f / 2$ medium with $\mathrm{N}, \mathrm{P}, \mathrm{Si}$, vitamins and trace metals minus $\mathrm{Zn}, \mathrm{Cu}$ and EDTA. To radiolabel the food, $74 \mathrm{kBq} \mathrm{l}{ }^{-1}$ of ${ }^{109} \mathrm{Cd}$ and the same amount of ${ }^{65} \mathrm{Zn}$ radioisotopes were added to the exponentially growing diatoms and maintained at $20^{\circ} \mathrm{C}$ with a $14 \mathrm{~h}$ light: $10 \mathrm{~h}$ dark light cycle for $2 \mathrm{~d}$. $\mathrm{NaOH}$ was added to neutralize the acid in the radioisotope carriers (in $0.1 \mathrm{~N} \mathrm{HCl}$ ). The radiolabelled diatom was collected by centrifugation $(2180 \times g)$ for $10 \mathrm{~min}$ at $20^{\circ} \mathrm{C}$ and resuspended in nonradioactive filtered seawater, which was repeated 5 times to minimize the desorption of the radiotracers during the radioactive feeding.

Individual scallops were placed in $300 \mathrm{ml}$ of $0.22 \mu \mathrm{m}$ filtered seawater, and radiolabelled food was added at a concentration of $5 \times 10^{4}$ cells $\mathrm{ml}^{-1}$. The scallops were allowed to feed on the radiolablled diatoms for $20 \mathrm{~min}$, then rinsed thoroughly with filtered seawater and assayed for their initial radioactivity, after which they were placed separately into polypropylene beakers held in a 10 l enclosed recirculating flow-through aerated seawater aquarium. Nonradioactive algae Thalassiosira nordenskioeldii were fed to the bivalves (every $2 \mathrm{~h}$ for the first $12 \mathrm{~h}$ and every $8 \mathrm{~h}$ for the following period) to promote the depuration of ingested radiolabelled food. The radioactivity in each bivalve was counted at frequent time intervals over $48 \mathrm{~h}$. The metal $\mathrm{AE}$ was determined as the percentage of the initial radioactivity retained in the bivalves after $48 \mathrm{~h}$ of depuration.

Metal efflux experiment. After the AE experiments, all the scallops were allowed to feed on radiolabelled diatoms again for $2 \mathrm{~h}$ each day using a well-established method (Wang et al. 1996). The feeding procedure continued for another $6 \mathrm{~d}$, after which all scallops were rinsed thoroughly and measured for initial radioactivity. Scallops were exposed only to radiolablled food, which was a dominant pathway for $\mathrm{Cd}$ and $\mathrm{Zn}$ accumulation in Chamys nobilis (Pan \& Wang 2008b). Wang et al. (1996) found that the exposure pathway (dietary and waterborne) and duration of labelling (12 h to $6 \mathrm{~d}$ ) had minor effects on metal efflux rate constant (except Ag) in the mussels Mytilus edulis. They were transferred to a $10 \mathrm{l}$ recirculating system containing nonradioactive seawater with aeration for $28 \mathrm{~d}$ of depuration. The radioactivities in the scallops were assayed regularly throughout the experiment. The efflux rate constant $\left(k_{\mathrm{e}}, \mathrm{d}^{-1}\right)$ was calculated from the slope of the regression between the natural log of the percentage of metals retained in the scallops and time. After the efflux experiment, all scallops were dissected and dry weights were obtained by drying the tissues in an $80^{\circ} \mathrm{C}$ oven.

Subcellular metal fractionation. In order to investigate the relationship between metal concentration and subcellular distribution in each individual, 30 scallops with a similar wet weight (1.6 to $1.8 \mathrm{~g}$ ) were subjected to subcellular fractionation using established methods (Wallace \& Luoma 2003, Pan \& Wang 2008c). Briefly, each scallop was dissected, and the soft tissue was dabbed dry to remove surface-bound seawater. The tissues were then homogenized in $5 \mathrm{ml}$ of $30 \mathrm{mM}$ Tris$\mathrm{NaCl}$ buffer ( $\mathrm{pH} 8.0 ; 0.15 \mathrm{M}$ sodium chloride; $5 \mathrm{mM}$ freshly prepared antiprotease, 2-mercaptoethanol; $0.1 \mathrm{mM}$ phenylmethylsulfonyl fluoride; Sigma-Aldrich). The homogenate was subjected to a series of treatments as described previously (Pan \& Wang 2008c), and 5 fractions were collected (cellular debris, metal-rich granule fraction [MRG], organelles and cytosolic proteins, such as heat-sensitive protein [HSP] and metallothionein-like protein [MTLP]). Control samples with no tissue addition were set up throughout the experiment and used as blanks for metal measurements. The subcellular distribution of the 2 metals 
was defined as the percentage of the total of each metal in each fraction.

Measurement of $\mathbf{C d}$ and $\mathrm{Zn}$ concentrations. After the dissolved metal uptake experiment, efflux experiment and subcellular fractionation, the scallop tissues were digested by addition of $2 \mathrm{ml}$ concentrated nitric acid (70\%, Fisher Scientific), which was heated at $110^{\circ} \mathrm{C}$ in an auto-regulated heating block for $2 \mathrm{~d}$. The oyster tissue standards (1566b, National Institute of Standards and Technology) were digested simultaneously. All the completely digested samples were diluted for quantification of $\mathrm{Cd}$ and $\mathrm{Zn}$ concentrations using the PerkinElmer AAnalyst 800 atomic absorption spectroscope (AAS). The recovery of $\mathrm{Cd}$ and $\mathrm{Zn}$ from the standard reference materials was between 95 and $110 \%$.

Radioactivity measurements and statistical analysis. The radioactivity was measured using a Wallac 1480 NaI (T1) gamma counter. All counts were related to standards and corrected for background noise. The gamma emission of ${ }^{109} \mathrm{Cd}$ was determined at $88 \mathrm{keV}$, and that of ${ }^{65} \mathrm{Zn}$, at $1115 \mathrm{keV}$. Counting times were adjusted to yield a propagated counting error of $<5 \%$. The statistical significance of the regressions was tested by analysis of variance, and the regressions were quantified by the coefficient of determination, $\mathrm{r}^{2}$.

\section{RESULTS AND DISCUSSION}

\section{Intraspecific variability of metal concentrations in scallops}

Scallops can accumulate $\mathrm{Cd}$ and $\mathrm{Zn}$ to very high concentrations. The highest measured concentrations of $\mathrm{Cd}$ and $\mathrm{Zn}$ were 24.9 and $785 \mathrm{\mu g} \mathrm{g}^{-1}$, respectively, indicating a strong accumulation capacity for $\mathrm{Cd}$ and $\mathrm{Zn}$ in scallops. Only a 3-fold range (ca. 7.3 to $24.9 \mu \mathrm{g} \mathrm{g}^{-1}$ ) was found for $\mathrm{Cd}$ concentrations in the present study, but the range for $\mathrm{Zn}$ was up to 10 -fold (ca. 67 to $785 \mu^{-1} \mathrm{~g} \mathrm{~g}^{-1}$ ) over a tissue dry weight of ca. 0.07 to 0.16 (Table 1), which is consistent with our previous observations
(Pan \& Wang 2008b). No significant relationship (p > $0.05)$ was found between metal concentration and tissue dry weight, suggesting that body size was not the controlling factor for variations in intraspecific metal concentrations in the chosen size range.

Metal bioaccumulation in aquatic invertebrates can be highly variable, and it is influenced by multiple routes of exposure (dietary and waterborne) and geochemical and biological factors. For example, between-site differences of metal concentrations in scallops can be explained by interactions among $\mathrm{AE}$, ingestion rates and growth rates caused by differences in food availability and quality (Pan \& Wang 2008a). There was also evidence of within-site variation in tissue metal concentrations (Gordon et al. 1980, Lobel et al. 1991). A wide range of metal concentrations of $\mathrm{Cd}$, $\mathrm{Cr}, \mathrm{Cu}, \mathrm{Pb}$ and $\mathrm{Zn}$ was found in barnacles and mussels collected from the same location in Hong Kong (Phillips \& Rainbow 1988). Oysters of similar sizes collected from an uncontaminated creek showed a 10-fold variation in $\mathrm{Cu}, \mathrm{Cd}$ and $\mathrm{Pb}$ concentrations (Robinson et al. 2005). Baldwin \& Maher (1997) argued that microhabitat variations, such as wave energy, shelter, recruitment and food availability contribute to the intraspecific metal concentration variability. Biological or physiological variables among different individuals are also important for intraspecific variability. Sexual differences in metal bioaccumulation have been reported, and significant changes in metal concentrations can be observed after spawning in bivalves (Metcalfe-Smith 1994). In our study, the scallops were too small to identify their sex, and thus the effect of sex on intraspecific metal variation is beyond the scope of our investigation.

Bioaccumulation of metals in aquatic animals is the net accumulation of metals in the tissue of the whole organism. It is well known that uptake rates from dissolved and dietary phases, elimination rates, as well as growth rates determine the metal concentrations in an organism. The history of metal exposure can also be important because it can alter these physiological

Table 1. Chlamys nobilis. Summary of biokinetic parameters in the bioaccumulation of Cd and Zn by scallops: dissolved uptake rate constant $\left(k_{\mathrm{u}}, \mathrm{n}=30\right)$, assimilation efficiency $(\mathrm{AE}, \mathrm{n}=57)$, efflux rate constant $\left(k_{\mathrm{e}}, \mathrm{n}=57\right)$, filtration rate $(\mathrm{FR}, \mathrm{n}=57)$, and metal body burden ( $\mathrm{n}=87$, tissue dry weight: 0.07 to $0.16 \mathrm{~g}$ )

\begin{tabular}{|c|c|c|c|c|c|c|c|c|c|}
\hline & \multicolumn{2}{|c|}{$-k_{\mathrm{u}}\left(\mathrm{l} \mathrm{g}^{-1} \mathrm{~d}^{-1}\right)-$} & \multicolumn{2}{|c|}{$\longrightarrow \mathrm{AE}(\%)-$} & \multicolumn{2}{|c|}{$k_{\mathrm{e}}\left(\mathrm{d}^{-1}\right)$} & \multirow{2}{*}{$\begin{array}{c}\text { FR } \\
\left(\mathrm{lg}^{-1} \mathrm{~d}^{-1}\right)\end{array}$} & \multicolumn{2}{|c|}{$\begin{array}{l}\text { Metal body burden } \\
\quad\left(\mu g^{-1} \text { dry wt }\right)\end{array}$} \\
\hline & $\mathrm{Cd}$ & $\mathrm{Zn}$ & $\mathrm{Cd}$ & $\mathrm{Zn}$ & $\mathrm{Cd}$ & $\mathrm{Zn}$ & & Cd & $\mathrm{Zn}$ \\
\hline Average & 0.890 & 1.457 & 77.6 & 76.5 & 0.0044 & 0.0241 & 35.0 & 16.2 & 287 \\
\hline $\mathrm{SD}$ & 0.0957 & 0.0548 & 1.46 & 1.4 & 0.0003 & 0.0017 & 1.5 & 0.4 & 14 \\
\hline Median & 0.915 & 1.439 & 81.8 & 76.6 & 0.0041 & 0.0214 & 31.3 & 16.2 & 261 \\
\hline Minimum & 0.668 & 0.798 & 46.7 & 53.1 & 0.0005 & 0.0046 & 16.2 & 7.3 & 67 \\
\hline Maximum & 1.05 & 2.78 & 95.8 & 97.1 & 0.0130 & 0.0609 & 67.2 & 24.9 & 785 \\
\hline
\end{tabular}


parameters (Wang \& Rainbow 2005). But growth rate, metal pre-exposure, as well as reproduction were not the dominant factors leading to the variability in our study, given the small and similar size and similar environmental conditions for the chosen scallops. As a result, analyses should focus on the relationships among the metal body burden and metal uptake rates from the dissolved phase $\left(k_{\mathrm{u}}\right), \mathrm{AE}$, and efflux rate.

\section{Metal biokinetics and metal concentrations}

The $k_{\mathrm{u}}$ and condition index for $\mathrm{Cd}$ and $\mathrm{Zn}$ did not vary much in the selected individuals. The range of $k_{\mathrm{u}}$ for Cd was ca. 0.668 to $1.050 \mathrm{l} \mathrm{g}^{-1} \mathrm{~d}^{-1}$ and that for $\mathrm{Zn}$ was ca. 0.798 to $2.78 \mathrm{l} \mathrm{g}^{-1} \mathrm{~d}^{-1}$ (Table 1). The metal uptake from the dissolved phase is a passively facilitated process following first-order kinetics. Previously, Wang (2001) suggested that $k_{\mathrm{u}}$ is positively related to the filtration rates of different species of marine bivalves. However, within a single species of bivalve, the filtration rate was not important in controlling individual variation in the dissolved metal uptake rate.

The retention of $\mathrm{Cd}$ and $\mathrm{Zn}$ in the scallops following pulse ingestion of radiolabelled diatoms is shown in Fig. 1. The AEs for both $\mathrm{Cd}$ and $\mathrm{Zn}$ were high (average $80 \%$ ) for the scallops, and they had a similar range of 50 to $95 \%$. Metal assimilation is controlled by abiotic (metal chemical behaviour, food quality and quantity) and biotic (body size, gut pass time) factors (Chong \& Wang 2000, Pan \& Wang 2008b). The gut passage time effectively explains the quality-dependent and interspecific AEs in bivalves, and a longer gut passage time leads to a higher metal AE (Wang 2003). However, this relationship is implicit for different individuals in a given species. The gut passage time was not evaluated in our study due to the large number of individuals tested. Wang \& Fisher (1996) showed that Cd and Zn assimilation efficiencies were directly related to carbon assimilation efficiencies. It is unclear if individual differences in AEs were directly caused by nutritional requirements.
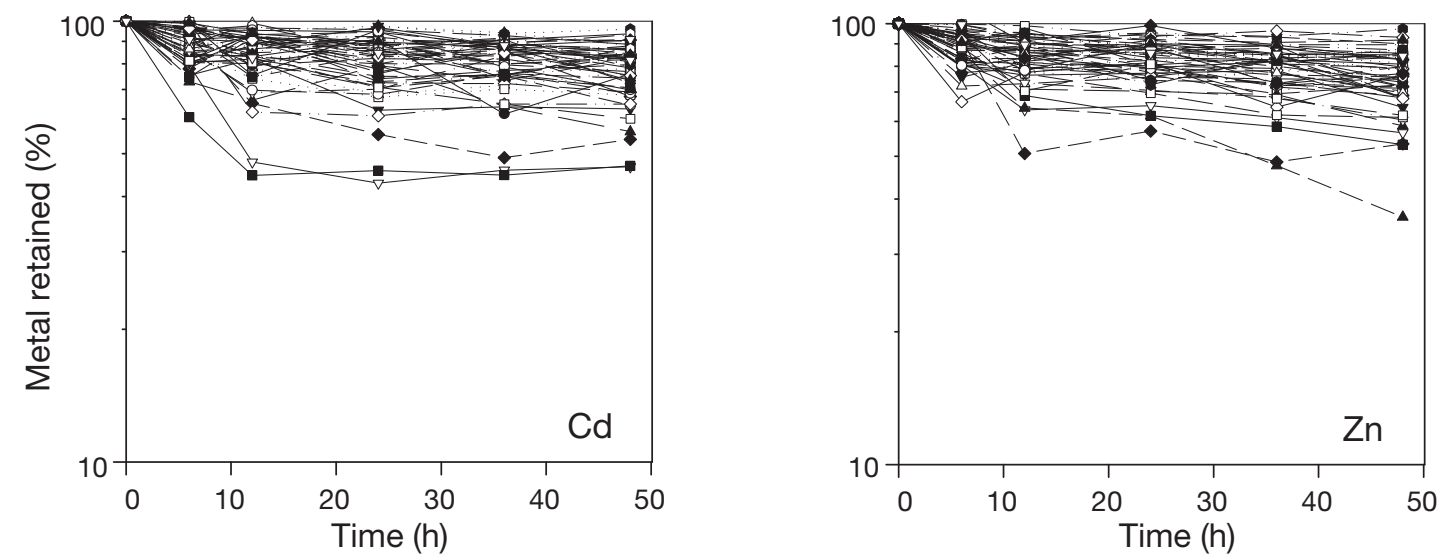

Fig. 1. Chlamys nobilis. Retention of $\mathrm{Cd}$ and $\mathrm{Zn}$ in 57 individual scallops following pulse feeding of radiolabelled diatoms and depuration for $48 \mathrm{~h}$. Each curve represents 1 individual scallop
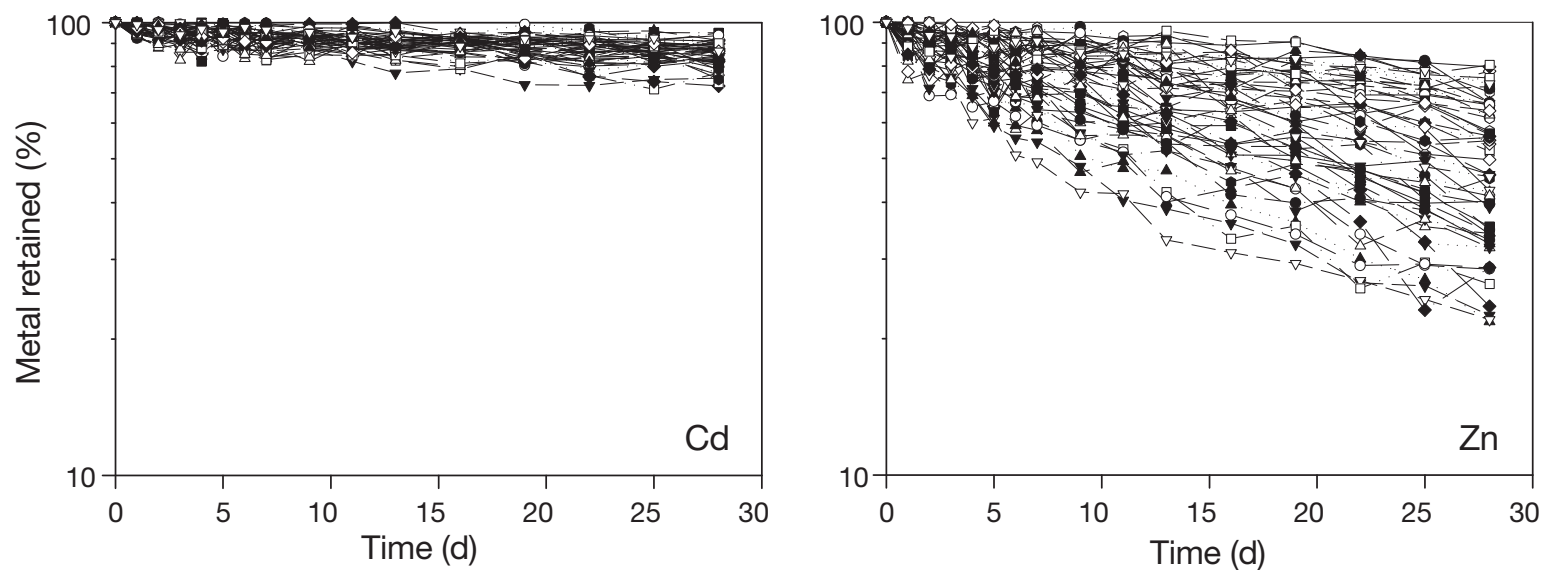

Fig. 2. Chlamys nobilis. Depuration of $\mathrm{Cd}$ and $\mathrm{Zn}$ in 57 individual scallops over a $28 \mathrm{~d}$ period following $7 \mathrm{~d}$ exposure to radioactive $\mathrm{Cd}$ and $\mathrm{Zn}$ in food. Each curve represents 1 individual scallop 
The depuration of metals from the scallops following $7 \mathrm{~d}$ of exposure to radiolabelled food is shown in Fig. 2. Contrasting depuration patterns were found between Cd and Zn. Most Cd (80 to 90\%) was efficiently retained by scallops, but Zn appeared to be eliminated faster in the majority of individuals, implying that Zn was more regulated in scallops than $\mathrm{Cd}$. Enormous variation in the metal efflux rates was found. For example, the efflux rate constant varied by 13 -fold for $\mathrm{Zn}$ and 26 -fold for $\mathrm{Cd}$ among the different individuals (Table 1).

A significant and positive relationship was found between $k_{\mathrm{u}}$ for $\mathrm{Cd}$ and $\mathrm{Zn}$ (Fig. 3), consistent with previous studies (Wang \& Dei 1999), indicating that Cd and $\mathrm{Zn}$ are presumably transported via the same pathway in the gills. A significant relationship was also found between the AEs of Cd and Zn (Fig. 3), indicating that the assimilation behaviour of 2 metals was similar. No significant relationship was found between $k_{\mathrm{u}}$ and metal body burden (Fig. 4) in the scallops. This result is not surprising since bioaccumulation of $\mathrm{Cd}$ and $\mathrm{Zn}$ in Chlamys nobilis is dominated by the dietary pathway (Pan \& Wang 2008b). The condition index (CI) was also not significantly related to metal body bur-
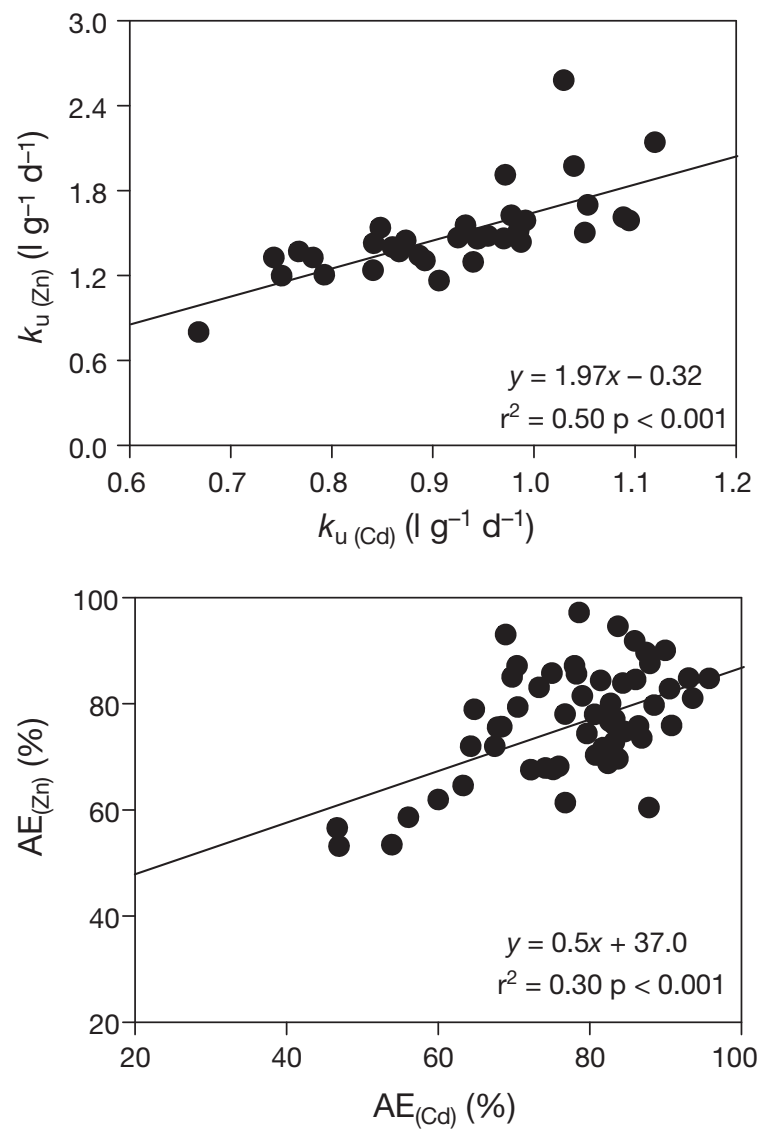

Fig. 3. Chlamys nobilis. Inter-relationships of dissolved uptake rate constants $\left(k_{\mathrm{u}}\right)$ and of assimilation efficiency (AE) in the scallop. Each data point represents 1 individual scallop den, probably because the CIs of the selected individuals were similar (Fig. 4). Using CI as an indicator of metal concentration in bivalves remains controversial. Mourgaud et al. (2002) found that CI was negatively related to metal body burden, but Webb \& Keough (2002) found that there was no direct relationship between the 2 parameters. Neither filtration rate (data not shown) nor AE had a significant relationship with metal body burden (Fig. 4).

A significant negative relationship was found between the efflux rate constant and metal body burden for both Cd and Zn (Fig. 4), however, which is consistent with our previous results that intraspecific differences in $\mathrm{Cu}$ body burden are mainly caused by the individual differences in the efflux rate of marine bivalves (Pan \& Wang 2009). The relationship was stronger for $\mathrm{Zn}$ than for $\mathrm{Cd}$, possibly due to the higher variability found for Zn body burden. These data strongly suggest that efflux is highly influential in regulating metal bioaccumulation in aquatic invertebrates, and small differences in efflux rates may have substantial effects on metal concentrations in aquatic animals. These data are the first to demonstrate the significant role of efflux in controlling the intraspecific differences in $\mathrm{Cd}$ and $\mathrm{Zn}$ metal concentrations in the tissues of bivalves.

\section{Subcellular distribution of metals in different individuals}

Metals are bound to different subcellular ligands in cells after removal from the environment (Viarengo \& Nott 1993). The subcellular distribution of metals in Chlamys nobilis is shown in Fig. 5. In general, $\mathrm{Cd}$ is sequestered in organelles and the MTLP fraction. Once in the cells, Cd can be bound to metallothionein (MT), which can be transported to lysosomes for degradation into insoluble residual bodies, either for longterm storage or excretion (Marigómez et al. 2002, Rainbow \& Luoma 2008). The Cd in the organelle fraction in our study was probably trapped in lysosomes involved in active intracellular digestion in the digestive gland in C. nobilis. MTLP was another important binding site for $\mathrm{Cd}$. The subcellular distribution of $\mathrm{Zn}$ exhibits a different pattern than that of $\mathrm{Cd}$. The cellular debris fraction is the major binding site (nearly $50 \%$ ), and $\mathrm{Zn}$ is distributed relatively evenly in the other fractions.

A significant positive relationship was found between the $\mathrm{Cd}$ body burden and organelles plus the MTLP fraction, and between the Zn body burden and the cellular debris fraction (Fig. 6). A strikingly strong inverse relationship was found between $\mathrm{Zn}$ body burden and cytosolic protein (HSP plus MTLP fraction) (Fig. 6), suggesting that scallops may regulate their 

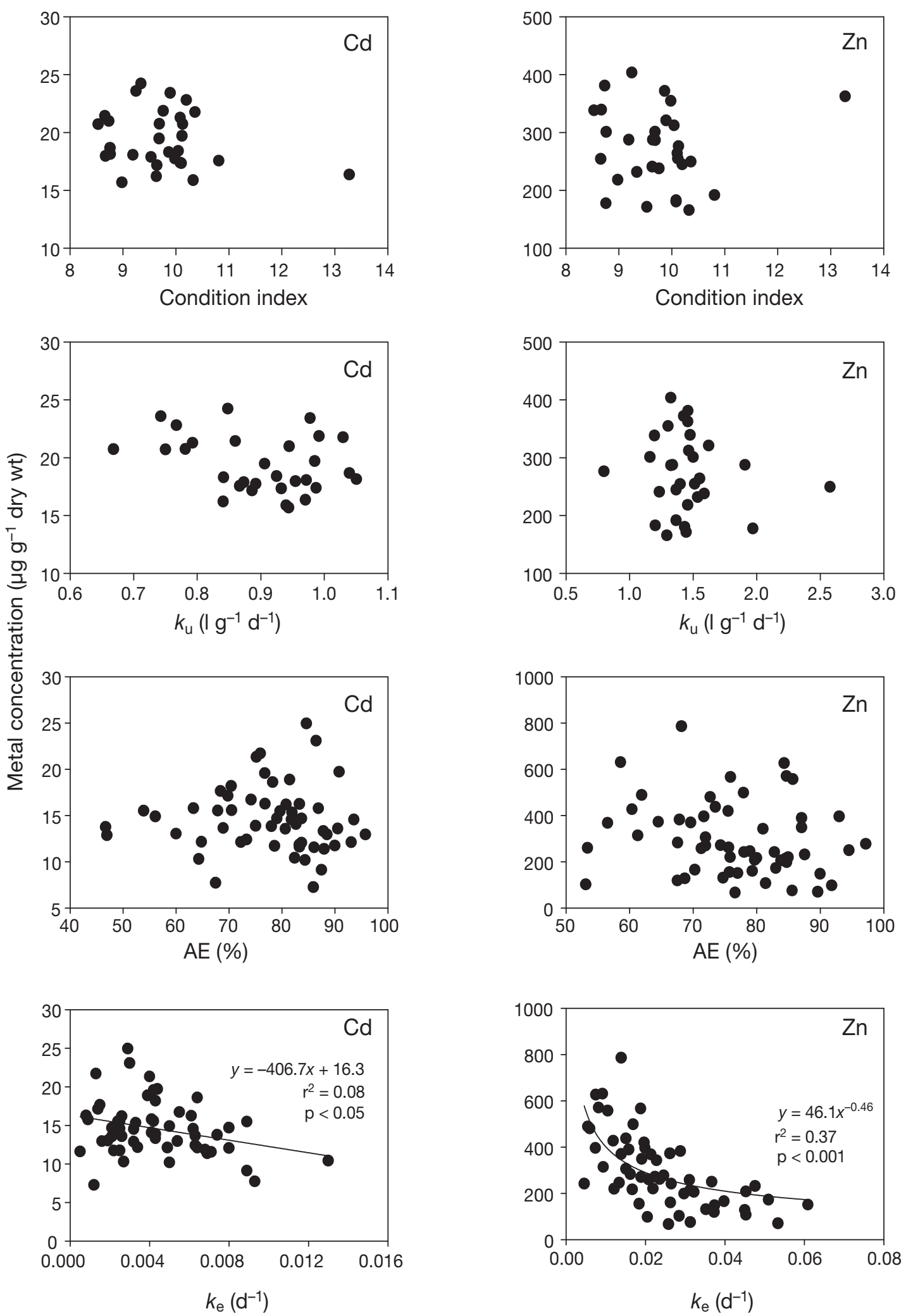

Fig. 4. Chlamys nobilis. Relationships between metal body burden and condition index $(\mathrm{n}=30)$, dissolved uptake rate constant $\left(k_{\mathrm{u}}, \mathrm{n}=30\right)$, assimilation efficiency $(\mathrm{AE}, \mathrm{n}=57)$ and efflux rate constant $\left(k_{\mathrm{e}}, \mathrm{n}=57\right)$. Each data point represents 1 individual scallop. Note a wider range of variation for metal concentrations in experiments with AE and efflux than in the experiment with dissolved metal uptake 


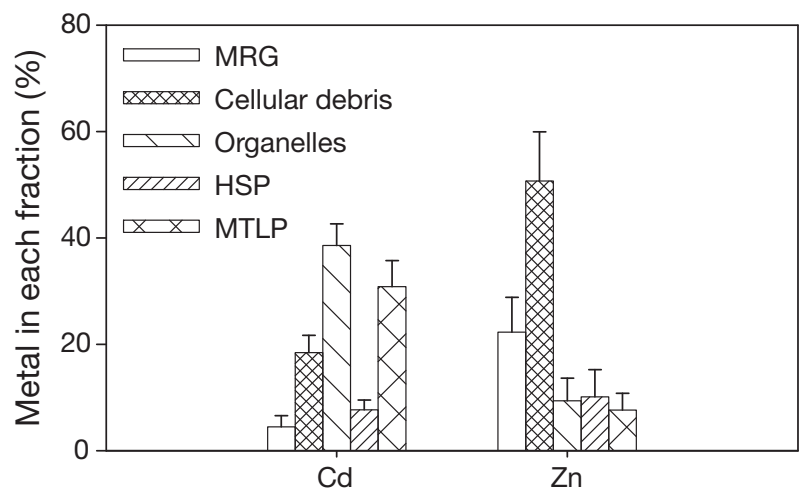

Fig. 5. Chlamys nobilis. Subcellular distribution of $\mathrm{Cd}$ and $\mathrm{Zn}$ in the scallop. MRG: metal-rich granules, HSP: heatsensitive protein, MTLP: metallothionein-like protein. Means $+\mathrm{SD}(\mathrm{n}=30)$ are shown

cytosolic Zn concentration to a stable level. This result was different from a previous report that the cytosolic Zn concentration was positively related to the whole body metal concentration in the clam Macoma balthica (Johansson et al. 1986). Overall, these results show that there are actual differences among individuals in terms of metal subcellular compartmentalization, which contributes to the intraspecific differences in metal bioaccumulation in scallops.

There are generally 2 functional strategies for aquatic invertebrates to avoid the toxic effects of metals. One is to reduce the net accumulation by reducing uptake or enhancing elimination, while the other is to increase the proportion of accumulated metal in nonbioreactive form (Morgan et al. 2007). It is believed that both pathways, whether simultaneously or mutually exclusive, must function effectively to suppress bioreactive metals under the critical body concentration (Vijver et al. 2004). For example, Perceval et al. (2006) suggested that excessive accumulation of $\mathrm{Cd}$ in the high molecular weight pool of the gill cytosol of individual molluscs contributed to their mortality at contaminated sites. In our previous study, we found that the percentage of $\mathrm{Cd}$ sequestered in organelles and that of $\mathrm{Zn}$ sequestered in the cellular debris fraction increased significantly during the $30 \mathrm{~d}$ depuration period (Pan \& Wang 2008c), indicating their important function in metal storage in Chlamys nobilis.

Significant differentiation may occur in the process of metal detoxification: the individuals with higher metal body burdens become more dependent on sequestering the metals in detoxified forms (MTLP and
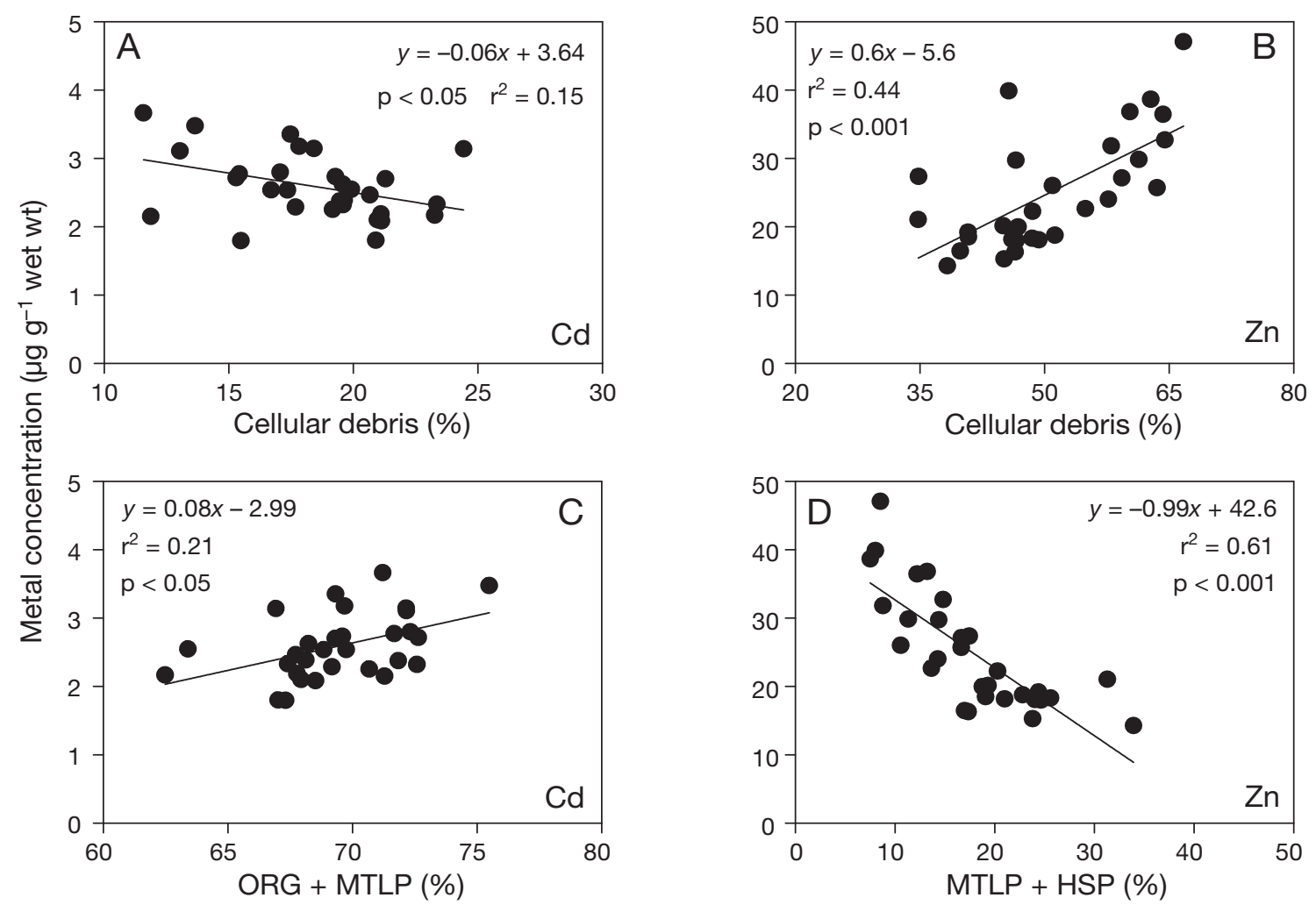

Fig. 6. Chlamys nobilis. Relationships between metal body burden ( $\mu \mathrm{g} \mathrm{g}^{-1}$ wet wt) and subcellular distribution of Cd (A,C) and Zn (B,D) in the following fractions: $(A, B)$ cellular debris; $(C)$ organelles (ORG) and metallothionein-like protein (MTLP); and (D) cytosolic protein (MTLP and heat sensitive protein [HSP]). See description in 'Results and discussion'. Each data point represents 1 individual scallop $(n=30)$ 
organelles for $\mathrm{Cd}$, cellular debris for $\mathrm{Zn}$ ), instead of metal elimination, than do those with lower metal body burdens. Buchwalter et al. (2008) found a potential trade-off between the ability to eliminate $\mathrm{Cd}$ and the ability to detoxify $\mathrm{Cd}$ in 21 aquatic insect species, and they speculated that elimination may be a better strategy than expressing proteins or peptides for metal detoxification by mayflies. Our results demonstrate that such a trade-off may also occur within a single species. Lobel et al. (1991) pointed to a similar result; metals that are stored in an insoluble form (granules) may exhibit higher levels of variability than metals stored in a soluble form. Our study had a similar finding that, for example, Zn was mainly stored in the insoluble form and was more variable than $\mathrm{Cd}$ in which a significant fraction was sequestered in the soluble form (MTLP).

The molecular and cytological mechanisms underlying metal subcellular differentiation remain unknown. Factors influencing intraspecific heterogeneities may include MT kinetics or turnover rates in different individuals, for example, up-regulation/ down-regulation of the MT gene and gene flow between polluted and unpolluted areas (Morgan et al. 2007, Janssens et al. 2008). Anthropogenic stressors in the environment can exhibit selection processes in genomes, and physiological traits associated with metal bioaccumulation/ detoxification may be formed in evolutionary history (Medina et al. 2007, Buchwalter et al. 2008). The phenotype of a field population possibly reflects both its multi-generational exposure history, as well as its genetic background, and natural selection acts on phenotypic variations between individuals in a population (Morgan et al. 2007). The diversity of metal-handling strategies can provide a population with more plasticity to counteract the spatially or temporally abrupt environmental changes and, thus, it is important for species survival of microevolutionary events. Zhulidov (1990) found that at polluted sites there were always some 'unusual' individuals (5 to $60 \%$ of the investigated number) of the earthworm Dendrobaena octaedra and mollusc Lymnaea stagnalis, as well as the Diplopod Rossiulus kessleri, the metal body burden of which did not appear to be affected by the elevated metal concentrations in the environment. Moreover, the variability (the range of metal concentrations of organisms) became more evident as the pollution level increased. A similar result was observed by Cravo \& Bebianno (2005) in that intra-population metal variability was higher at contaminated sites than at clean sites. Such results may indicate that intraspecific variability may actually reflect a species's ability to act against the toxicity of contaminants as well as to reverse adversity from the environment. Both detoxification pathways contribute to the tolerance for a given taxa in the environment.

\section{CONCLUSIONS}

Significant individual differences in metal bioaccumulation were found in the scallop Chlamys nobilis in our study. Contrasting metal efflux rates and metal subcellular distributions among different individuals were found to be important factors affecting the intraspecific heterogeneities of metal bioaccumulation. A low (high) efflux rate or a high (low) proportion of storage of metal in a non-toxic form is associated with a higher metal body burden in a population. Such intrinsic variation may be formed as a short-term response to an environmental stressor or over a timescale long enough to establish heritable physiological traits. The diversity of metal-handling strategies may provide a population more physiological plasticity to counteract the presence of elevated metal contaminants in the environment.

Acknowledgements. The present study was supported by a Competitive Earmarked Research Grant from the Hong Kong Research Grants Council (HKUST6420/06M) to W.-X. Wang.

\section{LITERATURE CITED}

Baldwin S, Maher W (1997) Spatial and temporal variation of selenium concentration in five species of intertidal molluscs from Jervis Bay, Australia. Mar Environ Res 44: 243-262

Buchwalter DB, Cain DJ, Martin CA, Xie L, Luoma SN, Jr TG (2008) Aquatic insect ecophysiological traits reveal phylogenetically based differences in dissolved cadmium susceptibility. Proc Natl Acad Sci USA 105:8321-8326

Bustamante P, Miramand P (2005) Evaluation of the variegated scallop Chlamys varia as a biomonitor of temporal trends of $\mathrm{Cd}, \mathrm{Cu}$, and $\mathrm{Zn}$ in the field. Environ Pollut 138:109-120

Cain DJ, Luoma SN (1986) Effect of seasonally changing tissue weight on trace metal concentrations in the bivalve Macoma balthica in San Francisco Bay. Mar Ecol Prog Ser 28:209-217

Chan KW, Cheung RYH, Leung SF, Wong MH (1999) Depuration of metals from soft tissues of oysters (Crassostrea gigas) transplanted from a contaminated site to clean sites. Environ Pollut 105:299-310

Chong K, Wang WX (2000) Assimilation of cadmium, chromium, and zinc by the green mussel Perna viridis and the clam Ruditapes philippinarum. Environ Toxicol Chem 19:1660-1667

Cravo A, Bebianno MJ (2005) Bioaccumulation of metals in the soft tissue of Patella aspera: application of metal/shell weight indices. Estuar Coast Shelf Sci 65:571-586

Crosby MP, Gale L (1990) A review and evaluation of bivalve condition index methodology with a suggested standard method. J Shellfish Res 9:233-237

> Daskalakis SD (1996) Variability of metal concentrations in oyster tissue and implications to biomonitoring. Mar Pollut Bull 32:794-801

- Gay D, Maher W (2003) Natural variation of copper, zinc, cadmium and selenium concentrations in Bembicium nanum and their potential use as a biomonitor of trace metals. Water Res 37:2173-2185 
Gordon M, Knauer GA, Martin JH (1980) Mytilus californianus as a bioindicator of trace metal pollution: variability and statistical considerations. Mar Pollut Bull 11:195-198

Janssens TKS, Lopéz RDR, Mariën J, Timmermans MJTN, Montagne-Wajer K, Straalen NMV, Roelofs D (2008) Comparative population analysis of metallothionein promoter alleles suggests stress-induced microevolution in the field. Environ Sci Technol 42:3873-3878

Johansson C, Cain DJ, Luoma SN (1986) Variability in the fractionation of $\mathrm{Cu}, \mathrm{Ag}$, and $\mathrm{Zn}$ among cytosolic proteins in the bivalve Macoma balthica. Mar Ecol Prog Ser 28:87-97

Kang SG, Wright DA, Koh CH (2000) Baseline metal concentration in the Asian periwinkle Littorina brevicula employed as a biomonitor to assess metal pollution in Korean coastal water. Sci Total Environ 263:143-153

Lobel PB, Belkhode SP, Jackson SE, Longerich HP (1991) Improved protocol for collecting Mussel Watch specimens taking into account sex, size, condition, shell shape, and chronological age. Arch Environ Contam Toxicol 21: 409-414

> Luoma SN, Rainbow PS (2005) Why is metal bioaccumulation so variable? Biodynamics as a unifying concept. Environ Sci Technol 39:1921-1931

Luoma SN, Rainbow PS (2008) Metal contamination in aquatic environments: science and lateral management. Cambridge University Press, New York

Marigómez I, Soto M, Cajaraville PM, Angulo E, Giamberini L (2002) Cellular and subcellular distribution of metals in molluscs. Microsc Res Tech 56:358-392

- Medina MH, Correa JA, Barata C (2007) Micro-evolution due to pollution: possible consequences for ecosystem responses to toxic stress. Chemosphere 67:2105-2114

Metcalfe-Smith JL (1994) Influence of species and sex on metal residues in freshwater mussels (family Unionidae) from the St. Lawrence River, with implications for biomonitoring programs. Environ Toxicol Chem 13:1433-1443

> Morgan AJ, Kille P, Stürzenbaum SR (2007) Microevolution and ecotoxicology of metals in invertebrates. Environ Sci Technol 41:1085-1096

- Mourgaud Y, Martinez E, Geffard A, Andral B, Stanisière JY, Amiard JC (2002) Metallothionein concentration in the mussel Mytilus galloprovincialis as a biomarker of response to metal contamination: validation in the field. Biomarkers 7:479-490

Mubiana VK, Vercauteren K, Blust R (2006) The influence of body size, condition index and tidal exposure on the variability in metal bioaccumulation in Mytilus edulis. Environ Pollut 144:272-279

Pan K, Wang WX (2008a) Validation of biokinetic model of metals in the scallop Chlamys nobilis in complex field environment. Environ Sci Technol 42:6285-6290

Pan K, Wang WX (2008b) Allometry of cadmium and zinc concentrations and bioaccumulation in the scallop Chlamys nobilis. Mar Ecol Prog Ser 365:115-126

Pan K, Wang WX (2008c) The subcellular fate of cadmium and zinc in the scallop Chlamys nobilis during waterborne and dietary metal exposure. Aquat Toxicol 90:253-260

Pan K, Wang WX (2009) Biodynamics to explain the difference of copper body concentrations in five marine bivalve species. Environ Sci Technol 43:2137-2143

Perceval O, Couillard Y, Pinel-Alloul B, Campell PGC (2006) Linking changes in subcellular cadmium distribution to growth and mortality rates in transplanted freshwater bivalves (Pyganodon grandis). Aquat Toxicol 79:87-98
Phillips DJH, Rainbow PS (1988) Barnacles and mussels as biomonitors of trace elements: a comparative study. Mar Ecol Prog Ser 49:83-93

Phillips DJH, Rainbow PS (1993) Biomonitoring of trace aquatic contaminants. Elsevier, Applied Science, London

Rainbow PS (2002) Trace metal concentrations in aquatic invertebrates: Why and so what? Environ Pollut 120: 497-507

Robinson WA, Maher WA, Krikowa F, Nell JA, Hand R (2005) The use of the oyster Saccostrea glomerata as a biomonitor of trace metal contamination: intra-sample, local scale and temporal variability and its implications for biomonitoring. J Environ Monit 7:208-223

> Viarengo A, Nott JA (1993) Mechanisms of heavy metal cation homeostasis in marine invertebrates. Comp Biochem Physiol C 104:355-372

Vijver MG, Gestel CAMV, Lanno RP, Straalen NMV, Peijnenburg WJGM (2004) Internal metal sequestration and its ecotoxicological relevance: a review. Environ Sci Technol 38:4705-4712

Wallace WG, Luoma SN (2003) Subcellular compartmentalization of $\mathrm{Cd}$ and $\mathrm{Zn}$ in two bivalves. II. Significance of trophically available metal (TAM). Mar Ecol Prog Ser 257: $125-137$

> Wang WX (2001) Comparison of metal uptake rate and absorption efficiency in marine bivalves. Environ Toxicol Chem 20:1367-1373

Wang WX (2003) Metal bioaccumulation in bivalve mollusks: recent progress. In: Villalba A, Reguera B, Romalde JL, Beiras R (eds) Molluscan shellfish safety. Intergovernmental Oceanographic Commission of UNESCO and Conselleria de Pesca e Asuntos Maritimos da Xunta de Galicia, Santiago de Compostela, Spain, p 503-520

Wang WX, Dei RCH (1999) Factors affecting trace element uptake in the black mussel Septifer virgatus. Mar Ecol Prog Ser 186:161-172

Wang WX, Fisher NS (1996) Assimilation of trace elements and carbon by the mussel Mytilus edulis: effects of food composition. Limnol Oceanogr 41:197-207

Wang WX, Rainbow PS (2005) Influence of metal exposure history on trace metal uptake and accumulation by marine invertebrates. Ecotoxicol Environ Saf 61:145-159

Wang WX, Rainbow PS (2008) Comparative approaches to understand metal bioaccumulation in aquatic animals. Comp Biochem Physiol C 148:315-323

Wang WX, Wong P (2006) Dynamics of trace metal concentrations in an intertidal rocky shore food chain. Mar Pollut Bull 52:332-356

Wang WX, Fisher NS, Luoma SN (1996) Kinetic determinations of trace element bioaccumulation in the mussel Mytilus edulis. Mar Ecol Prog Ser 140:91-113

> Webb JA, Keough MJ (2002) Measurement of environmental trace-metal levels with transplanted mussels and diffusive gradients in thin films (DGT): a comparison of techniques. Mar Pollut Bull 44:222-229

Zauke GP, Petri G (1993) Metal concentrations in Antarctic crustacea: the problem of background levels. In: Dallinger $\mathrm{R}$, Rainbow PS (eds) Ecotoxicology of metals in invertebrates.. Lewis Publishers, Boca Raton, FL, p 73-101

Zhulidov AV (1990) Analysis of the factors determining the concentration of heavy metals in animal bodies as the bioindication of the environment's condition. In: Krivolutsky DA (eds) Bioindications of chemical and radioactive pollution. CRC Press, Boca Raton, FL, p 251-301

Submitted: February 17, 2009; Accepted: March 18, 2009

Proofs received from author(s): April 30, 2009 